\title{
Wild men in Braunschweig - Economies of hope and fear in early modern mining ${ }^{*}$
}

\author{
Tina Asmussen
}

Gaining one's subsistence from the mines in the early modern Harz region meant getting along with the Wild Man. A late seventeenth-century origin myth concerning the mining town of Wildemann in the region of the Upper Harz in north central Germany tells of encounters between local miners and these hairy beasts. When the first miners arrived in the Upper Harz, they learned of a Wild Man and a Wild Woman living together in the area. Despite their best efforts, the miners could never catch the beasts. Their search for rich, ore-bearing veins in the local rock likewise proved fruitless. Nevertheless, the day came where the miners' fortunes turned. In hunting down the Wild Man, they wounded him so badly that he was unable to move, and got caught. The miners tried to force the creature to work, but he refused. Nor would he speak, eat, or drink. He just gazed back up to the mountains, as if he could not bear being separated from his home. Upon the duke's order the Wild Man was transported to the courtly residence, but unfortunately died on the way. Astonishingly, on the very same day, the miners discovered rich silver veins in the rock. They were convinced that the Wild Man had protected the mineral resources from being found and it was only through his death that they could

\footnotetext{
*Earlier versions of this article were presented at the Renaissance Society of America Annual Conference in Berlin and in the doctoral colloquium of Dept. II at the MPIWG. I wish to thank the audience for their valuable comments. I'm also grateful to Sebastian Felten, Marius Buning, Jonathan Regier for commenting on my thoughts and drafts, and to the two anonymous readers for their suggestions. Wolfgang Leschhorn introduced me to the numismatic collection of the Anton Ulrich-Museum in Braunschweig. I'm grateful to him for sharing his numismatic knowledge with me.
} 
access the subterranean riches. In honour of the creature they named the first silver mine 'Old Wild Man'.

Although these stories never state precisely when this encounter happened, nor give the name of the reigning duke, the local myth connects the presence of wild folk in a specific rural territory with the subterranean realm of precious metals.

From about the sixteenth century onwards the Wild Man - a figure who was ubiquitous in medieval and early modern German culture, particularly in medieval art and literature (going far beyond the confines of the Middle Ages) ${ }^{2}-$ became a point of identity for the early modern mining industry in the Harz: mining pits and towns were named after him, he was a prominent character in local festive traditions, he was a bearer of the coat of arms for the Welf dynasty, notably for the Dukes of Braunschweig-Wolfenbüttel, and most prominently, his image came to adorn the reverse of a new form of silver money, thaler coins, in the 1530s. The figure of the Wild Man was used as an emblem on medals and coins coming from the Harz mints until the beginning of the nineteenth century. ${ }^{3}$ This ever increasing presence of the Wild Man in the area around Wolfenbüttel in the sixteenth century can be contextualized within the broader reception of this folkloric creature and his transformation into a figure signifying a national identity. As Stephanie Leitch has convincingly shown, the fashioning of the Wild Man as an 'ur-German' ancestor, which was motivated by the rediscovery of Tacitus' Germania in 1473, linked humanist explorations of the past to a search for the

\footnotetext{
${ }^{1}$ Gerhard Heilfurth, Bergbau und Bergmann in der deutschsprachigen Sagenüberlieferung Mitteleuropas (Marburg: N. G. Elwert Verlag, 1967), 232-5. A second origin myth from an earlier date is transmitted by Johannes Praetorius. But in this account the relation between the Wild Man and the ores are missing: 'In year of Christ 1240, two Satyrs or wild men with long tails have been caught in the Harz, the female was stabbed during the haunt and died. The male, in contrast, survived, was tamed, walked upright, learned to talk, but cried often like a deer or goat, lacked any reason and also did not feel ashamed when ripping down women while being in rut. Therefrom, without any doubt the mining town Wildmann, the place where it was caught, as well as the Wildmen coins got their names four hundred years ago.' [Im Jahre Christi 1240/ Haben sich auf dem Hartze zween Satyri oder Wilde Menschen fangen lassen mit langen Schwäntzen/ das Weiblein ward unter der Jagd gestochen/ daß es starb. Das Männlein aber blieb lebendig/ ward zam gemacht/ ging aufgerichtet/ lernet reden/schrie aber offt wie ein Rehe oder Ziege/ hatte keine Vernunfft/ schämete sich auch nicht/ in Brunst riß es offte Frauen nieder. Dahero ohn Zweiffel das Bergstädtlein Wildmann woselbst es vielleicht gefangen: Item die Wildenmänner Thaler/ ihre Namen bekommen haben vor vierhundert Jahren.] Johannes Praetorius, Anthropodemus Plutonicus Das ist/ Eine Neue Welt-beschreibung von allerley Wunderbahren Menschen [I] (Magdeburg: Lüderwald, 1668), 710.

${ }^{2}$ Richard Bernheimer, Wild Men in the Middle Ages: A Study in Art, Sentiment, and Demonology (Cambridge Mass.: Harvard University Press, 1952); Roger Bartra, Wild Men in the Looking Glass: The Mythic Origins of European Otherness, tr. Carl T. Berrisford (Ann Arbor: University of Michigan Press, 1994); Timothy Husband, The Wild Man. Medieval Myth and Symbolism (New York: Metropolitan Museum of Art, 1980); Edward Dudley, Maximillian E. Novak (eds.), The Wild Man Within: An Image in Western Thought from Renaissance to Romanticism (Pittsburgh; University of Pittsburgh Press, 1972).

${ }^{3}$ Fritz Spurth, Oberharzer Ausbeutetaler von Braunschweig-Lüneburg im Rahmen der Geschichte ihrer Gruben. Ein Beitrag zur Industriearchäologie (Bochum: Deutsches Bergbau-Museum Bochum, 1986), esp. 27-31; HansHermann von Scotti, Ausbeutetaler und Medaillen des Harzer Bergbaus (Goslar: Selbstverlag, 1988), 35.
} 
origins of the Germans. ${ }^{4}$ In the following I will concentrate on the links between mining, minting, and myth in order to tease out the intrinsic logics of the early modern mining industry. Such aspects are often lost sight of within a history of technology and economy aligned to the transformative, capitalist character of mining that has become so dominant in the industrial age. ${ }^{5}$

Economic and social historians have carefully worked out how mining's revival and expansion in the later fifteenth century brought an influx of outsiders to the mainly rural settings of the Erzgebirge, the Tyrol, and the Harz Mountains. Peasants were drawn away from their traditional livelihoods and increasingly began to earn an income as Häuer [hewers] in the mines. ${ }^{6}$ Migration and new working conditions brought social differentiation and rapid change into these rural settings, which were furthermore altered by the founding of mining towns and the introduction of urban institutions, mentalities, and values. ${ }^{7}$ East German economic historians have even gone so far as to consider the emerging group of miners as a proletariat in a proto-Marxist

\footnotetext{
${ }^{4}$ See Stephanie Leitch 'The Wild Man, Charlemagne and the German Body', Art History, 31 (2008), 283302; Stephanie Leitch, 'Chapter 3. The Wild Man, the German Body, and the Emperor's New Clothes', idem, Mapping Ethnography in Early Modern Print Culture. New Worlds in Print Culture (New York: Palgrave Macmillan, 2009), 37-62. This chapter contains also further details about the Amerindian Wild Man, which this present article does not consider.

${ }^{5}$ Angelika Westermann (ed.), Wirtschaftslenkende Montanverwaltung, fürstlicher Unternehmer, Merkantilismus. Zusammenhänge zwischen der Ausbildung einer fachkompetenten Beamtenschaft und der staatlichen Geld- und Wirtschaftspolitik in der Frühen Neuzeit (Husum: Matthiesen Verlag, 2009); Christoph Bartels, Vom frühneuzeitlichen Montangewerbe zur Bergbauindustrie: Erzbergbau im Oberharz 1635-1866 (Bochum: Deutsches Bergbau Museum Bochum, 1992). In current research the developments of the mining academies in Freiberg, Schemnitz (today Banská Štiavnica) and Berlin play an important role. See especially Ursula Klein, 'Savant Officials in the Prussian Mining Administration', Annals of Science, 69 (2012), 349-74; idem, Nützliches Wissen. Die Erfindung der Technikwissenschaften (Berlin: Wallstein Verlag, 2016); Peter Konečný and Hartmut Schleiff (eds.), Staat, Bergbau und Bergakademie, Montanexperten im 18. und frühen 19. Jahrhundert (Stuttgart: Steiner Verlag, 2015); Wolfhard Weber, 'Erschliessen, Gewinnen, Fördern: Bergbautechnik und Montanwissenschaften von den Anfängen bis zur Gründung Technischer Universitäten in Deutschland', in Wolfhard Weber and Jens Adamski (eds.), Salze, Erze und Kohlen: Der Aufbruch in die Moderne im 18. und frühen 19. Jahrhundert, Geschichte des Deutschen Bergbaus, Vol. 2 (Münster: Aschendorff, 2015), 217-408; Andre Wakefield, The Disordered Police State: German Cameralism as Science and Practice (Chicago: University of Chicago Press, 2009); Andre Wakefield, 'The Fiscal Logic of the Enlightened German Science', in Pamela H. Smith and Benjamin Schmidt (eds.), Making Knowledge in Early Modern Europe: Practices, Objects, and Texts, 1400-1800 (Chicago: University of Chicago Press, 2007), 273-86.

${ }^{6}$ Susan C. Karant-Nunn, 'Between Two Worlds: The Social Position of the Silver Miners of the Erzgebirge, c. 1460-1575', Social History, 14 (1989), 307-22, esp. 312ff.

${ }^{7}$ Karl-Heinz Ludwig, 'Bergmännisches Berufsbewusstsein als Protestpotential im Mittelalter und im Übergang zur Frühen Neuzeit', in Angelika Westermann and Ekkehard Westermann (eds.), Streik im Revier. Unruhe, Protest und Ausstand vom 8. bis 20. Jahrhundert (St. Katharinen: Scripta-Mercaturae-Verl., 2007), 11-63; Erich Egg, 'Die Bergleute als neuer Berufsstand im Schwazer Silberbergbau 1450-1550', in Karl-Heinz Ludwig and Peter Sika (eds.), Bergbau und Arbeitsrecht: die Arbeitsverfassung im europäischen Bergbau des Mittelalters und der Frühen Neuzeit (Wien: VWGÖ, 1989), 211-22; Angelika Westermann, 'Berg- und Hüttenarbeiter in der ländlichen Gesellschaft Vorderösterreichs in der Frühen Neuzeit', in Mark Häberlein and Martin Zürn (eds), Minderheiten, Obrigkeit und Gesellschaft in der Frühen Neuzeit: Integrations- und Abgrenzungsprozesse im süddeutschen Raum (St Katharinen: Scripta-Mercaturae-Verl., 2001), 75-108. With regards to the emerging mining towns see especially the contributions in the edited volume by Karl Heinrich Kaufhold, Wilfried Reininghaus (eds.), Stadt und Bergbau (Cologne: Böhlau Verlag, 2007); Angelika Westermann, 'Bergstadt und Montankultur 1350-1850, in Weber and Adamski (eds.), Salze, Erze und Kohlen, 409-560.
} 
sense. ${ }^{8}$ Social historians later rejected this view of a collective class-consciousness - this was too simple an explanation of the complex social phenomenon the emerging group of miners represented, which modern terms only awkwardly describe. Nevertheless a specific form of social distinctiveness has still been acknowledged. ${ }^{9}$

The history of mining in the Harz, taking the material and symbolic evidence of the Wild Man into consideration, instead means to undercut this transformative and modernizing narrative by articulating the unarticulated, invisible, and the resilient - and to do so without simply arguing for a countermovement, which in the case of mining means to put emphasis on tradition, and the continuity of knowledge and beliefs. It reveals how the perception of the ore mines as sites of unlimited possibilities, technological innovation, holders of countless treasures, but also as places of death and fear, dominated the social, cultural, and economic aspects of early modern mining activity.

The Wild Man, as I will show, plays an important role in human interactions with metallic materials, as he points to the symbolic and emotional dimensions of the early modern mining rush. Focusing on this mythic figure, this article aims to broaden economic history's insistence on material and empirical evidence by examining imaginary and affective qualities such as the promises and expectation of finding metal ores, the materialization of desires, as well as the productivity of hope and fear. Far from being of secondary relevance, this perspective contributes to a history of mining as a sociocultural phenomenon in its own right - a phenomenon constituted by the entanglement of the actors' economic practices and techniques with meaning-making affects and emotions. By emphasizing the mystical, symbolic, and affective qualities of the Wild Man, my analysis of early modern mining and coinage in the Harz region sheds light on the ambiguity of technological innovation, the notion of material wealth, and the promise of precious metals.

\section{MINING IN THE HARZ MOUNTAINS}

From about 1524 onward, Duke Heinrich the Younger of BraunschweigWolfenbüttel (1489-1568) systematically set about reviving mining and metal production in the northwestern part of the Harz in Zellerfeld and Wildemann,

\footnotetext{
${ }^{8}$ Adolf Laube, Studien über den erzgebirgischen Silberbergbau von 1470 bis 1546: Seine Geschichte, seine Produktionsverhältnisse, seine Bedeutung für die gesellschaftlichen Veränderung und Klassenkämpfe in Sachsen am Beginn der Übergangsepoche vom Feudalismus zum Kapitalismus (Berlin: Akademie-Verlag, 1974); Johann Köhler, Die Keime des Kapitalismus im sächsischen Bergbau, 1168 bis um 1500 (Berlin: Akademie Verlag, 1955).

${ }^{9}$ Karant-Nunn does not agree that Saxon miners achieved collective class-consciousness in the sixteenth century, but she sees some similarity between Saxon miners' labour and the later proletarian mode of production, see Susan C. Karant-Nunn, 'From Adventurers to Drones: The Saxon Silver Miners as an Early Proletariat', in Thomas M. Safley (ed.), The Workplace Before the Factory: Artisans and Proletarians, 1500-1800 (Ithaca: Cornell University Press, 1993), 74.
} 
areas belonging to the so-called Upper Harz. ${ }^{10}$ As with the mining boom in Saxony, Bohemia, and Tyrol during the second half of the fifteenth century, a new era of mining began, characterized by its labour- and capital-intensive nature. In a relatively short space of time, valuable silver began to be mined at Grund, Wildemann, and Zellerfeld. The silver was then directly turned into coins in the local mint. The rural environment of the Upper Harz began to change rapidly as a result of the revived mining activity. The loose settlements quickly transformed into mining towns, which Duke Heinrich bestowed with city rights, such as Zellerfeld in 1529 and Wildemann in 1534. The latter was named after a bountiful mining pit that the miners had baptised 'Wild Man'."

Yet, in comparison to the mining regions in the Saxon and Bohemian parts of the Erzgebirge, valuable metalliferous ores were far less plentiful in the Upper Harz mining areas. The sixteenth-century origin myth of the Rammelsberg, a mining site in the northern part of the Harz Mountains, next to the imperial city of Goslar, mentions that the ores were abundant, but their silver content was rather poor. Lazarus Ercker (1528-1594), a sixteenth-century assayer that later became an imperial mining official, recounts the legend in his 1565 treatise on the Rammelsberg: while on a hunting trip, a knight called Ramm, who was a vassal of Emperor Otto the Great, tied his horse to a tree in order to stalk game in the rugged terrain on foot. Impatient for the return of his master, the horse pushed the ground with a hoof, and exposed an ore vein that led to an ore deposit. Ramm brought a specimen of ore to the Emperor, who consulted an assayer. It turned out that the silver and lead content was rather poor, but nevertheless the Emperor ordered that a mine be set up here, which he named 'Rammelsberg' after his knight. The emperor's

\footnotetext{
${ }^{10}$ For a more detailed analysis of the specificities of the early modern mining industry in the Harz Mountains see especially the very rich work of Christoph Bartels, Hans-Joachim Kraschewski and Ekkehard Henschke. Christoph Bartels, 'The Production of Silver, Copper, and Lead in the Harz Mountains from Late Medieval Times to the Onset of the Industrialization', in Ursula Klein and Emma C. Spary (eds.), Materials and Expertise in Early Modern Europe. Between Market and Laboratory (Chicago: University of Chicago Press, 2010), 71-100; Bartels, Vom frühneuzeitlichen Montangewerbe zur Bergbauindustrie; Hans-Joachim Kraschewski, 'Bergbau und Hüttenwesen', in Karl Heinrich Kaufhold, Jörg Leuschner, and Claudia Märtl (eds.), Die Wirtschafts- und Sozialgeschichte des Braunschweigischen Landes vom Mittelalter bis zur Gegenwart (Hildesheim: Olms 2008), 689-735; Hans-Joachim Kraschewski, 'Der Bergbau des Harzes im 16. und zu Beginn des 17. Jahrhunderts', in Werner Kroker and Ekkehard Westermann (eds.), Montanwirtschaft Mitteleuropas vom 12. bis 17. Jahrhundert. Stand, Wege und Aufgaben der Forschung, Der Anschnitt. Zeitschrift für Kunst und Kultur im Bergbau, Beiheft 2 (Bochum: Deutsches Bergbau-Museum, 1984), 134-43; with regards to the development of the mining administration in the Harz see especially the seminal studies of Ekkehard Henschke and Hans-Joachim Kraschewski: Ekkehard Henschke, Landesherrschaft und Bergbauwirtschaft: zur Wirtschafts- und Verwaltungsgeschichte des Oberharzer Bergbaugebietes im 16. und 17. Jahrhundert (Berlin: Dunker and Humblot, 1974); Ekkehard Henschke, 'Die Wolfenbütteler Herzöge und der Bergbau im Harz', Braunschweigisches Jahrbuch für Landesgeschichte, 88 (2007), 71-88; Hans-Joachim Kraschewski, 'Organisationsstrukturen der Bergbauverwaltung als Element des frühneuzeitlichen Territorialstaates. Das Beispiel Braunschweig Wolfenbüttel', in Niedersächsisches Jahrbuch für Landesgeschichte, 80 (2008), 283-328.

${ }^{11}$ Heinrich Morich and Herbert Dennert (eds.), Die keine Chronik Oberharzer Bergstädte und ihres Erzbergbaus (Clausthal-Zellerfeld: Piepersche Verlagsanstalt, 1974), 128.
} 
decision to start mining in this spot turned out to be very wise, because the output was tremendous, 'in the whole Christendom such huge masses of ore have never been found in one single mountain until the present day'. ${ }^{12}$

As the legend of the imperial hunter Ramm indicates, sourcing metals in the Harz was not an easy task, but nevertheless extraction sites here ranked among the most important silver, lead, and copper mines in early modern central Europe. The main deposit between Wildemann and Zellerfeld was a particular case in point, where the desired metal was quite difficult to extract. The invasion of groundwater was a constant problem for the miners. Long adits (horizontal tunnels for working or draining a mine) had to be newly driven, and those from earlier periods had to be restored and extended. This demanded a huge number of skilled workmen, hard bodily labour, expensive machines, as well as costly technical and metallurgical procedures.

One of the most significant characteristics of Renaissance mining was the high mobility of miners, smelters, mint masters, and assayers. Word of rich silver findings in the Harz spread widely and rapidly. The term Berggeschrey [mountain clamour] was coined by contemporaries to describe this phenomenon - it points to a process of economic dynamism and the circulation of people, knowledge, materials, and money at a frantic pace. But the clamour's intensity and impulsiveness bears also an affective dimension, meaning that actors were driven by material desires, hopes, and fears. Many miners were attracted by the promises of the newly found natural riches. By proclaiming freedoms and privileges for those willing to come to his territory, Duke Heinrich enticed miners further, and recruited experts from Saxony and Bohemia. $^{13}$

\footnotetext{
12 'Es schreiben die alten Sachsen und ist eine gemeine Rede zu Goslar/ Das der Rammelsbergk wunderbarlicher weis erfunden sey. Nemlich zue den zeitten Kaiser Otten des Ersten/ welcher wonete uf der Harzburgk und vielfeldig in den Harzgebirgen jagen lies/ begab sichs auff eine zeit/ Das seiner vornemen Jeger einer mit namen Ramm/ aus befehl des Keysers an den vorbergen des Hartzes jagete [...] als der Jeger an einem ort von wegen der höhe des Berges dem Wildt nit mehr nach eylen kund/ heftet er sein Pferd an einen Baum [...] Dieweil er aber dem Wildt fern folgen musst/ verlanget des Jegers Pferd nach seinem Herrn/ und scharret heftig an den Berge/ Wie sein Herr der Jeger Ramm wiederumb zu seinem Pferdt kam/ sahe er wie sein Pferdt so hart gearbeittet hett/ und viel Stein aus der Erden geschart [...] und hub darunter auff eine/ bracht die dem Keyser Otten [...] wiewol sich das Ertz gantz gering an Silber und Bley erzeigt hat/ hat doch der Keyser aus liebe die er zum Berckwergk getragen/ mit Berckleutten den Berck gewaldig angriffen/ und mit schürfen vorsuchen lassen/ da hat man das Ertz in solcher gar grossen mengen antroffen/desgleichen in der Christenheit biss auf diessen Tagk in einem Berck allein/ nicht gefunden ist.' Lazarus Ercker, Vom Rämelsbergk vnd desselbigen Berckwergks ein kurtzer bericht (Erfurt: Georg Baumann d. Ä., 1565), IIr-v. For further information on the practitioner and metallurgist Lazarus Ercker, see Pamela O. Long, 'The Openness of Knowledge: An Ideal and its Contexts in Sixteenth-Century Writings on Mining and Metallurgy', Technology and Culture, 32 (1991), 318-55, esp. 346-50; Ludmila Kubátová, Hans Prescher, and Werner Weisbach (eds.), Lazarus Ercker (1528/30-1594): Probierer, Berg- und Münzmeister in Sachsen, Braunschweig und Böhmen (Leipzig: Dt. Verl. für Grundstoffindustrie, 1994); Lazarus Ercker - sein Leben und seine Zeit: zur Geschichte des Montan- und Münzwesen im mittleren Europa, ed. Technische Universität Bergakademie Freiberg (Freiberg: Technische Universität, 1994).

${ }^{13}$ Heinrich asked Stephan Schlick, count of St Joachimsthal, for mining experts who would successfully establish mining in his duchy. See, Henschke, Landesherrschaft und Bergbauwirtschaft, esp. 42-56; Manfred von Boetticher, 'Herrschaft und mittelalterliche Montanindustrie: Der Bergbau in Böhmen, Erzgebirge und Harz und seine Wechselbeziehungen', Niedersächsisches Jahrbuch für Landesgeschichte, 80 (2008), 1-14.
} 
It was not only skilled workmen and metallurgical experts who were attracted by the promises of riches and thus migrated to the Harz; investors were also keen to profit from the mines. Since the transport and installation of hoists, ventilation and pumping systems, hammers for crushing ores, and smelteries for ore processing were extremely expensive, the flow of capital had to be guaranteed via shared investment. For contemporary mining investors the purchase of Kuxen [mining shares] was a very attractive venture. ${ }^{14}$ If the yields were abundant, they were paid with 'good' money; mostly fine silver coins coming directly from the mining town's mints. ${ }^{15}$ The increase of silver production went therefore hand in hand with an increase of silver coins that led to the dominant currency (the Rhenish gold guilder) gradually being replaced by silver. ${ }^{16}$

In 1531 Heinrich the Younger followed on the heels of the Saxon and Bohemian rulers and founded a mint within the walls of the monastery of Reichenberg, where he started to produce fine silver coins, named thaler, with silver from the Upper Harz mines.

In 1538 the duke issued a new series of thaler, minted with Heinrich's portrait on the obverse and the symbol of the powerful figure of legend and folklore, the Wild Man, on the reverse (Fig. 1). The hairy creature wears no clothes and is holding a tree trunk in his right hand and an ore specimen in his left. He is frontally depicted, with his genitals obviously exposed. He seems to be moving, walking out of the edge of the coin. The deep connection

\footnotetext{
${ }^{14}$ By the end of the fifteenth century Kuxen appeared as a legal form in Saxon mining ordinances and spread to all major mining districts in Middle Germany and Further Austria. One Kux guaranteed profit sharing from the mining of precious and semi-precious ores. Each mine in the districts of Saxony and Bohemia was divided into several Kuxe - normally 128 - which people of any rank and from anywhere could buy in mining towns and the cities of fair trade. By investing their money in Kuxe these people became shareholders of a certain mine. This form of investment was extremely successful. See Adolf Zycha 'Das Wort Kux', Zeitschrift für Bergrecht, 62 (1921), 407-12; Judy Mendels, 'Die Etymologie des Wortes Kux', Modern Language Notes, 76 (1961), 336-41; Richard Dietrich, Untersuchungen zum Frühkapitalismus im mitteldeutschen Erzbergbau und Metallhandel (Hildesheim: Olms 1991); Friedrich-Wilhelm Wellmer and Wolfgang Lampe, 'Spekulation mit Bergbauaktien: Kuxen im 17. Jahrhundert im Vergleich zu heute. Hat sich die Risikobereitschaft in der Exploration über 300 Jahre verändert?', Der Anschnitt, 66 (2014), 25-31; Tina Asmussen, 'The Kux as a Site of Mediation: Economic Practices and Material Desires in the Early Modern German Mining Industry', in Susanna Burghartz, Lucas Burkart, and Christine Göttler (eds.), Sites of Mediation - Connected Histories of Places, Processes, and Objects in Europe and Beyond, 1450-1650, Intersections. Interdisciplinary Studies in Early Modern Culture 47 (Leiden: Brill, 2016), 159-82. Shared investment played also a crucial factor within the mining revival in the Harz Mountains, see: Ursula Schmidt, Die Bedeutung des Fremdkapitals im Goslarer Bergbau um 1500 (Goslar: Selbstverlag, 1970).

${ }^{15}$ Paul Arnold, 'Bergbau und Münzwesen', in Manfred Bachmann, Harald Marx and Eberhard Wächtler (eds.), Der silberne Boden: Kunst und Bergbau in Sachsen (Stuttgart: Edition Leipzig 1990), 43.

${ }^{16}$ The idea of a silver equivalent to the gold guilder emerged in Tyrol at the end of the fifteenth century, and around 1500 silver coins named Guldengroschen and later Taler appeared in Saxony. Philipp Robinson Rössner, 'Die (proto-)globalen Spannungsfelder und Verflechtungen mitteldeutscher Münz- und Währungspolitik um 1500. Das Beispiel der sächsischen Talerprägung', in Martina Schattkowsky and Helmut Albrecht (eds.), Das Erzgebirge im 16. Jahrhundert: Gestaltwandel einer Kulturlandschaft im Reformationszeitalter (Leipzig: Leipziger Universitäts-Verlag, 2013), 103-57.
} 

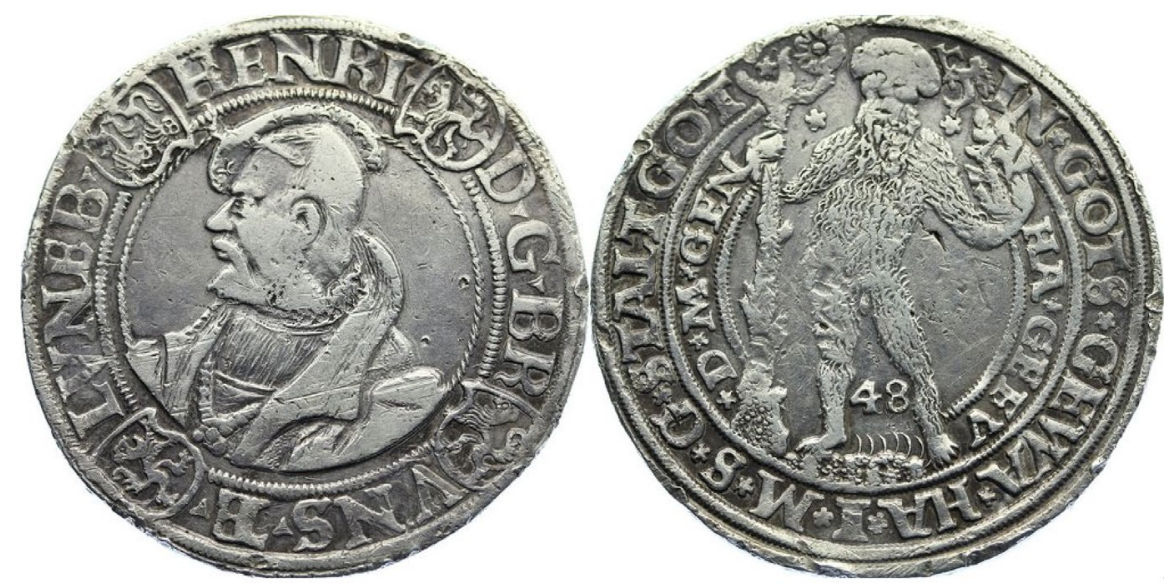

Fig. 1 Wilder Mann thaler, Heinrich the Younger of Braunschweig-Lüneburg, mint of Riechenberg 1548, $28.51 \mathrm{~g}$ of silver, $41 \mathrm{~mm}$. Niedersächsisches Münzkabinett der Deutschen Bank Hannover (@ Niedersächsisches Münzkabinett der Deutschen Bank Hannover)

between the Wild Man and mineral and wooden resources is clearly signified by the ore specimen and the trunk. This type of Wild Man thaler is a completely new creation, inspired by local legends and folklore.

Traditionally, images of saints adorned coins, although portraits of rulers were increasing; the depiction of pagan beasts on money had not yet been seen. ${ }^{17}$ By adopting the Wild Man as a symbol on the currency, Heinrich the Younger might have wished to alert potential investors to the rise of his new mining town to a position of some importance, locally and in the region, and to advertise the increasing silver yield of the Upper Harz. Through their high circulation, excellent visibility, and mobility coins served as a useful medium through which to promote an authoritative message. The two elements, the introduction of silver coins and the motif of the Wild Man were closely connected with the productivity of the duke's lands and the solvency of his mines.

\section{MINING DEMONS, WILD MEN, AND THE REALM OF SILVER}

Miners in the early modern period had to face extreme working conditions, as is still the case today. They constructed their tunnels at great depths under the earth, with what they referred to as Schweiß und blutsawre Arbeit [sweat and blood-sour work], and were constantly under threat from collapsing shafts,

\footnotetext{
${ }^{17}$ Wolfgang Leschhorn, Braunschweigische Münzen und Medaillen: 1000 Jahre Münzkunst und Geldgeschichte in Stadt und Land Braunschweig (Braunschweig: Appelhans, 2010), 105; Gustav Heyse, 'Der Wilde Mann auf Braunschweig-Lüneburgischen Münzen', Zeitschrift des Harz-Vereins für Geschichte und Altertumskunde, 3[1870] no 3 (1871), 650-6, Eduard Jacobs, 'Der Wilde Mann als Sinnbild des Hartzes', in Ibid., 656-69.
} 
invading groundwater, and toxic fumes. In Georgius Agricola's (1494-1555) foundational text De re metallica (1556) the author reflects on voices critical of mining, who see the essential danger involved as reason enough to avoid such activity. Those opposed to the endeavour believe that

mining is a perilous occupation to pursue, because the miners are sometimes killed by the pestilential air which they breathe; sometimes their lungs rot away; sometimes the men perish by being crushed in masses of rock; sometimes, falling from the ladders into the shafts, they break their arms, legs, or necks. ${ }^{18}$

The risky and precarious working conditions affected the miners' perception of nature, life, and death in manifold ways.

The hard labour and extreme experience of work underground made mining an ideal frame of reference for the emergence of countless myths and legends. Gerhard Heilfurth's collection of Bergmannssagen (miners' myths) is still an essential reference for historians of early modern mining. ${ }^{19}$ These legends deal predominantly with hope, threat, uncertainty, and chance in different locations and contexts all over Europe. The Harz region produced a huge amount of miner's legends that are tightly connected to the essential precariousness of the mining venture. By reading these sources the notion of the mines as sites of danger and uncertainty becomes evident and transforms mining into an area of ambiguity; on the one hand a divine gift and a gateway to untold wealth, on the other a sure path to the unforeseen and life-threatening.

Hardanus Hake (d. 1611), a sixteenth-century pastor of Wildemann, reports in his chronicle of Harz mining from around 1580 how a Deamon Metallicus that the miners called Berg Männlein, and which took the form of a friar, haunted the rich pit Wilder Mann. This evil spirit protected the silver ores, frightened the miners, and caused great damage. ${ }^{20}$ Paracelsus (around 14931541) discussed the interconnection of rich ore-bearing veins and spirits at length. ${ }^{21}$ The presence of demons in the mines was also a belief that Agricola noted. In his text Bermannus sive de re metallica [Bermannus or a Dialogue on Metallurgy] (1530) the learned miner Bermann explains the ambivalent nature of mining demons:

\footnotetext{
${ }^{18}$ Georgius Agricola, De re metallica. Translated from the first Latin edition of 1556 with biographical introduction, annotations and appendices upon the development of mining methods, metallurgical processes, geology, mineralogy and mining law from the earliest times to the 16th century, ed. Herbert Clark Hoover and Lou Henry Hoover (New York: Dover, 1950), 6 .

${ }^{19}$ Heilfurth, Bergbau und Bergmann.

${ }^{20}$ Hardanus Hake, Die Bergchronik des Hardanus Hake, Pastor zu Wildemann, ed. Heinrich Denkern (Wernigerode: Harzverein für Geschichte und Altertumskunde, 1911), 11.

${ }^{21}$ Paracelsus, 'De occulta phlosophia', in idem, Sämtliche Werke, 1. Abteilung: Medizinische, naturwissenschaftliche und philosophische Schriften, Vol. 14, ed. Karls Sudhoff (Munich: R. Oldenbourg, 1933), 523-4.
} 
Some of them do the miners no harm, they only stroll through the galleries, and they seem to work. Sometimes they hollow a gallery, sometimes they fill carriers with extracted material, sometimes they move the hoisting machine, and sometimes they tease the workers. They preferably do this in mines where rich ores are to be extracted or where there is at least hope to find much silver. Others in contrast are actually most harmful, such as the mining spirit who viciously attacked miners in the pit called Rosenkranz [Rosary] in Annaberg several years ago, where twelve of them died. Many people know this story and they have abandoned the pit although it is rich. ${ }^{22}$

Early modern miners as well as contemporaneous treasure hunters were highly alert to such supernatural phenomena, since they knew very well that these figures always promised riches. But how were these mining demons connected with Duke Heinrich's Wild Man, and the ore specimen he demonstratively holds in his hands?

According to Paracelsus, the Wild Man is a creature of flesh and blood, similar to humans, but lacking a soul and therefore has no sense of God. Moreover, he is characterized as being coarse, rough, tall, and strong, but with a shy nature. ${ }^{23}$ The Wild Man shuns human contact, 'settling, if possible, in the most remote and inaccessible parts of the forest, and making his bed in crevices, caves, or the deep shadow of overhanging branches'. ${ }^{24}$ As becomes evident through these few characterizations, the Wild Man is a creature from the woods or remote unpopulated areas. Any relation to ores is not indicated. But the naming of pits after the wild forest creature was quite common, and is a tendency that had been in evidence since the late fifteenth and early sixteenth century in mining districts in Freiberg and Schneeberg. It is possible nevertheless that the Wild Man migrated along with the miners from the Erzgebirge to the Harz; among the first pits that the miners dug in the Upper Harz one can find a site named Wilder Mann.

The Wild Man indicates an environment that is uncanny, raw, unpredictable, foreign, and uncultured. This is exactly the sort of terrain where promises of untold riches grow and the lure that one may get hold of such treasure hangs in the air. Richard Bernheimer, in his analysis of the mythical personality of the Wild Man, elaborates in great detail on the dual nature of the wild folk. He disclosed the relationship between the Wild Man Silvanus, benefactor

\footnotetext{
22 'ut io camur genus certe dæmonum in fodinis nonnullis versari compertum est: quorum quidam nihil damni metallicis inferunt, sed in puteis vagantur, ac laboribus cum nihil agant, se exercere videntur: nunc cavando venam, nunc ingerendo in situlos id quod effossum est, nunc machinam versando tractoriam, nunc iritando operarios, idem potissimum faciunt in his specubus è quibus multum argentum effoditur, vel magna eius inveniendi spes est. Alii vero noxii admodum sunt, ut ille qui ante aliquot annos Annebergi in fodina cui nomen Corona Rosacea, tantopere infestabat metallicos, ut duodecim, quæ res multis nota est, nescarit, ac ea de re fodina, quantumuis argento dives esset, relicta fuit.' Georgius Agricola, Bermannus sive de re metallica (Basel: Froben, 1530), 38-9.

${ }^{23}$ Paracelsus, 'De occulta philosophia', 523 and idem, 'De nymphis, sylphis, pygmaeis et salamandris et de caeteris spiritibus', in Sämtliche Werke, Vol. 14, 148-9.

${ }^{24}$ Bernheimer, Wild Men, 9.
} 
of the woods and indicator of natural wealth, and Wild Man Orcus, the Roman god of death and the underworld, enemy of all living things and of humankind itself. ${ }^{25}$ He pointedly characterized the Wild Men as figures of mediation between life and death:

[...] on the side of life their care for the animals and their readiness to make their advice available to the human community; and on the side of death their appalling ugliness, cannibalism, frightful temper, and wilderness habitat, unfit for any spectral occupants, and finally their predilection for hail and storm, the weather most suitable for the return of the dead. ${ }^{26}$

Therefore, the Wild Man is benevolent and evil at one and the same time. $\mathrm{He}$ is an image of desire, because as a demon he shares nature's secrets and is in possession of arcane and useful knowledge, but he is also an image of ferocity, terror, and punishment. This characteristic mediation between life and death made the Wild Man an ideal personification of the uncertain, dangerous, but at the same time promising mining industry, and - as we will later see - of the monetary economy as a whole.

\section{THE MINE AS A SITE OF HOPE AND FEAR}

Early modern literature on mining and metallurgy was fuelled by the rapid expansion of mining as an industry. Discussions on material wealth and financial profit were crucial themes. The mention of the pits' enigmatic names, which included Hoffnung [hope], Gabe Gottes [gift of God], reicher Segen des Herrn [abundant blessing of the Lord], Treue [faithfulness], or Fortuna [goddess of fortune] evoked associations among contemporaries about rich silver mines or even deposits of native silver provided by divine providence. The mining texts and chronicles that had been appearing since the early sixteenth century popularized fantastic stories about marvellous silver outputs and how indigent or ordinary people acquired enormous wealth by finding a fertile silver mine. Furthermore, they stress the inexhaustible natural riches still hidden in the Earth, awaiting discovery. The German territories were, as they believed, especially gifted with mineral resources. ${ }^{27}$ But they also mention the downside of the mining enterprise by giving examples of the many unfortunate individuals who fell into debt following their failed efforts at the mines. The miners' and mining investors' emotional balance thus mediated between hope for abundant riches and fear of financial wreck, hazards, and death and turned the practice of mining into the practice of risk.

${ }^{25}$ Ibid., 43-4.

26 Ibid., 44.

27 'Equidem nunc Germaniam cæeteris regionibus \& præstantius argentum habere [...]', Agricola, Bermannus, 81; Dietrich Lohrmann, 'Harald Kühn, Aenea Silvio Piccolomini und der Reichtum Deutschlands am Ende des Mittelalters', Geschichte in Wissenschaft und Unterricht, 7/8 (1997), 384-98. 
Georgius Agricola exposes in his dialogue Bermannus the profound knowledge and practical skills a learned miner must possess regarding the nature and composition of ores, about the various technologies needed for their extraction, and the procedures for processing ores. But besides knowledge and skill, emotions play a crucial role in this text. The treatise is composed as a dialogue between Bermann, a learned miner, and two physicians, Naevius and Ancon. At the offset, a dispute among these men occurs, as to whether or not choosing to invest in mining is a wise decision. Although Bermann ardently defends the view that mining is a good investment, where many have acquired incredible riches with little effort, he asserts that there is no certainty in this business; each person who wants to engage successfully in mining requires courage and hope. Bermann says 'one always has to hope; the likes of us [meaning, the miners] possess nothing except hope. ${ }^{28}$ However, his opinion is highly disputed by his interlocutor Ancon, who does not see why he should participate in such a venture where only 'hope' is guaranteed. Bermann counters,

Your exaggerated caution will always be an impediment! You will never become a good miner, and never rich. With this excessive caution a farmer would never sow, because he must fear a disaster. Nor would a merchant trade overseas, as he must reckon with a shipwreck. And no one would do his military service, as the outcome of every war is uncertain. But everyone relies on hope, and in most cases this works out well. No one has ever made anything with a weak and timid heart, and nor will he bring it to a conclusion. ${ }^{29}$

The specific risk mentality that becomes evident in Bermann's speech is sewn like a red thread through sixteenth- and seventeenth-century mining manuals. Even Paracelsus, in his medical work Von der Bergsucht und anderen Bergkrankheiten [On the Miners' Sickness and Other Diseases of Miners] (1530) dryly states that there is no gain without the danger of losing one's life. ${ }^{30}$

When taking risks, miners had positive or negative expectations of the future outcome, which they expressed in emotions of hope and fear. Both feelings, hope and fear, are the positive and negative expectations connected

28 'Sperandum omnino est, siquidem præter spem nostris interdum nihil est [...]'. Agricola, Bermannus, 30.

29 'Nimia ista tua providentia obstavit, quo minus vel unquam bonus metallicus vel dives quò peripatetico aspirare liceret, fias. Atque hac certe ratione neq; agricola sereret, quia timidenda sit calamitas, neq; mercator navigaret, quia naufragium pertimescendum, neque quisquam in militiam iret, quia incertus sit belli exitus, sed bene sperant omnes et feliciter sæpius procedit, nemo vero animo qui abiecto et timido fuit unquam rem fecit aut etiam faciet', see Agricola, Bermannus, 30-1.

30 'Darbey auch gold vnd silber müssen wir haben, auch andere metallen, eisen, zihn, kupffer, bley, quecksilber, so wir dasselbigen haben wollen, so müssen wir darbey wagen leib vnd leben, mit fienden so gegen vns standen, also auch so wir ander dingen haben wollen, das wir zu nutz vnsers gesondes lebens gezwungen werden zugebrauchen, so ist nichts, das nit vnseren feind mit ihm trage.' Paracelsus, Von der Bergsucht und anderen Bergkrankheiten, ed. Irmgard Müller (Berlin: Springer, 2013), 44 [11r Tractat III, 1. capitel]. 
to something desired or needed, which have a cognitive as well as an affective dimension. ${ }^{31}$ Knowledge and skill as well as hope, fear, desire, and need were therefore factors integral to the sense- and decision-making processes that encouraged the miners to go down into the darkness, take on the dangerous task of mining, hoping to be successful. This ambiguity that is so crucial for the mining industry is inextricably tied up with the ambivalent notion towards wealth and money in Christian society. ${ }^{32}$

Many mining treatises emphasize the negative aspects of natural riches, which are the raw material for money, tools, and arms. Georgius Agricola, for example, opens De re metallica (1556) with a display of contemporary moral criticism on the mining rush and, in good humanist tradition, draws heavily from classical sources such as Pliny, Ovid, and Aristophanes. Mining and metallurgy are denounced for being the reason for humanity's cultural decay, which becomes manifest in deteriorating morality, the origins of property, self-interest, crime, aggression, and war. But all these examples possess a complementary aspect, because there are many economic, social, and cultural benefits that emerged from the mining industry as well, including the advantage of the monetized economy over the barter economy, the economic utilization of uncultivated land, the provision of employment, and the spread of education and religion. ${ }^{33}$ A direct predecessor of Agricola's narrative is a fictional work entitled Iudicium Iovis, written by the Bohemian humanist Paulus Niavis (around 1460-1517) between 1485 and $1490 .{ }^{34}$ In a mythological court setting Mother Nature sues the miner. She appears maltreated, bloody, and tearful in front of a judge represented by Jupiter. Nature accuses the miner of violent treatment caused by his greedy search for natural riches. Contrary to convention, Niavis departs from the Classical view at a crucial point in the story. He does not excoriate humans for their cruel exploitation of Mother Nature; with a certain brash tone he excuses and even defends human activity by blaming nature's lavish distribution of riches. Man is supposed to exploit and therefore wound nature in order to guarantee his subsistence. The final word on this trial goes to Fortuna:

\footnotetext{
31 Andreas Bähr, 'Die Furcht in der Frühen Neuzeit. Paradigmen, Hintergründe und Perspektiven einer Kontroverse', Historische Anthropologie, 16 (2008), 291-309; idem, Furcht und Furchtlosigkeit: Göttliche Gewalt und Selbstkonstitution im 17. Jahrhundert (Göttingen: V \& R Unipress, 2013).

${ }^{32}$ Jared Poley, The Devil's Riches: A Modern History of Greed (New York: Berghahn Books, 2016).

33 Agricola, De re metallica libri XII, (Basel: Froben, 1556), Book 1; for classic traditions of humanist arguments against the exploitation of nature see Horst Bredekamp, 'Der Mensch als Mörder der Natur. Das 'Iudicium Iovis' von Paulus Niavis und die Leibmetaphorik', Vestigia Bibliae, 6 (1984), 261-83; Horst Bredekamp, 'Die Erde als Lebewesen: Leibmetaphorik und Magie', Kritische Berichte, 4/5 (1981), 5-37.

${ }^{34}$ Paulus Niavis, Iudicium Iovis in valle amenitatis habitum ad quod mortalis homo a terra propter montifodinas in Monte Niveo aliisque multis prefectas ac demum parricidii accusatus (n.p., n.d); for a German translation see, Paulus Niavis, Iudicium Iovis oder das Gericht der Götter über den Bergbau. Ein Literarisches Dokument aus der Frühzeit des deutschen Bergbaus, tr. Paul Krenkel (Berlin: Akademie Verlag, 1953).
} 
It's human's destiny to ransack mountains; they have to dig pits, they have to cultivate lands, and do trading business. By doing this they have to offend nature, they have to reject the sciences, disturbing Pluton and even search in waterways for ores. But their body will be devoured by the Earth, suffocated by poisonous airs; it gets drunk from wine and suffers hunger - but, there's a good thing about it: no one knows all these dangers of any type that simply cannot be separated from human beings. Good bye. ${ }^{35}$

Since the pagan goddess Fortuna has the last word, the miner's activities are depicted as constantly teetering on the brink of the abyss, similar to Fortuna's balancing on the globe. Miners had to factor in risk if they were to get their rewards. The Wild Man, the Bergmännlein, or the Bergmönch function as figures that shed a certain light on the human desire for riches, by simultaneously giving emphasis to the precariousness of achieving a happy outcome. Moreover, they also indicate the morally and physically destructive potential of such ventures. These figures came into being at a time of environmental and economic change, and when people, landscapes, materials, and money circulated at a quickened pace. The natural economy where wild folk lived without the benefit of agriculture and metallurgy was opposed to new industrialized landscapes and a monetary economy.

\section{THE WILD MAN OF WOLFENBÜTTEL}

Duke Heinrich's Wild Man thaler aptly illustrates this ambivalence between natural wealth (ore) and artificial wealth (money). ${ }^{36}$ On the one hand it points to the natural riches of the Harz Mountains and to dreams of hidden treasure. On the other, it points to the volatile and unstable nature of natural resources and the monetary system as a whole.

The economic situation during the Central European mining boom of the sixteenth century was marked by an increase in prices and a gradual devaluing of the currency. Although silver production in the German mining regions increased, there was a constant lack of bullion. ${ }^{37}$ 'Good' silver coins with a

\footnotetext{
35 'Es ist die Bestimmung der Menschen, dass sie Berge durchwühlen; sie müssen Erzgruben anlegen, müssen Felder bebauen und Handel treiben. Dabei müssen sie bei der Erde Anstoß erregen, müssen die Wissenschaft ablehnen, den Pluton beunruhigen und auch in den Wasserläufen nach Erzen suchen. Ihr Leib aber wird von der Erde verschlungen, durch böse Wetter erstickt; er wird trunken vom Weine, er leidet Hunger - aber, was sehr gut ist: keiner kennt die vielen Gefahren sonstiger Art, die nun einmal vom Menschen unzertrennlich sind. Lebe wohl.' Ibid., 38.

${ }^{36}$ On the ambivalence between natural wealth and money see also Henrike Haug's article in this volume.

${ }^{37}$ Hans-Jürgen Gerhard, 'Ursachen und Folgen der Wandlungen im Währungssystem des Deutschen Reiches 1500-1625: Eine Studie zu den Hintergründen der sogenannten Preisrevolution', in Eckart Schremmer (ed.), Geld und Währung vom 16. Jahrhundert bis zur Gegenwart (Stuttgart: Franz Steiner Verlag, 1993) 69-84; Paul Arnold, 'Das sächsische Münzwesen in der ersten Hälfte des 16. Jahrhundert: Die Wechselbeziehungen zwischen Bergbau und Münzpolitik in Sachsen', in Friedrich Naumann (ed.), Georgius Agricola: 500 Jahre (Basel: Birkhäuser, 1994), 416-22; Philipp R. Rössner, 'Bad Money, Evil Coins? Coin Debasement and Devaluation as Instruments of Monetary Policy on the Eve of the "Price Revolution", in idem (ed.), Cities - Coins - Commerce: Essays presented to Ian Blanchard on the Occasion of his 70th Birthday (Stuttgart: Franz Steiner Verlag, 2012), 89-119; idem, Deflation - Devaluation - Rebellion: Geld im Zeitalter der Reformation (Stuttgart: Franz Steiner Verlag, 2012).
} 
high content of precious metal were rare items in sixteenth- and seventeenth-century payment transactions. 'Good' coins were regularly melted down, silver was extracted for reasons of governmental or personal profit and 'evil' coins with a much lower silver content were produced with some part of the silver. Fine silver coins were therefore perceived not only as good currency, but also a highly desirable commodity.

This fraught financial situation led to a huge political debate on currency and coinage. There were continuous negotiations concerning the intrinsic value and exchange rates of coins. Many treatises of the sixteenth century dealt with an increase in prices and a draining of good coins occurring at the same time as a flood of bad ones; for example Martin Luther (1483-1546), Nicolaus Copernicus (1473-1543), and Georgius Agricola elaborated on the subject from perspectives of theology, political economy, and natural history. ${ }^{38}$ They took their lead from Aristotelian monetary philosophy and argued for the intrinsic value of coins. Following Nicole Oresme (c.1330-1382) they considered the manipulation of currency - particularly debasement - as a form of usury. $^{39}$

A look at the princely decrees of Heinrich the Younger and his successors shows that these rulers were constantly concerned about their currency, and condemned deceitful mint masters or other figures threatening governmental order. Duke Heinrich used the symbolic idea of the Wild Man to legitimize his silver thaler as an uncorrupted medium of exchange - the inscription non vidi justum derelictum [I have never seen a just man abandoned] (Psalm 36: 25) relates the coin's material and authoritative nature to the Wild Man, who represents an uncorrupted race. The Wild Man, thus, ennobles the coins, turning them into objects with pure natural value. Similarly, in contemporary monetary theory, coins not only serve as a medium for measurement and exchange but also as a commodity, thanks to their intrinsic content of precious metal. In his metrological treatise De precio metallorum et monetis [On the Price of Metals and Coins] (1550) Agricola stated 'The good coins are treasures (thesaurus). Whoever possesses silver and gold coins knows exactly what he has; they have the same value everywhere. ${ }^{, 0}$ But by establishing the coin as a pure and natural form of value by means of the symbolic image of the Wild Man, the

\footnotetext{
${ }^{38}$ Hermann Kellenbenz, 'Die Vorschläge des Nicolaus Copernicus zu einer Reform des preußischen Münzwesens', in Hermann Kellenbenz H. (ed.), Dynamik einer quasi-statischen Welt (Stuttgart: Franz Steiner Verlag 1991), 571-86; Georgius Agricola, Schriften über Masse und Gewichte (Metrologie), Vol. 5, ed. and tr. Georg Fraustadt and Hans Prescher (Berlin: Deutscher Verlag der Wissenschaften, 1959); Luther Martin, Von Kauffshandlung und Wucher (Wittenberg, Hans Lufft: 1524).

${ }^{39}$ Oresme Nicolas, De mutatione monetarum tractatus - Traktat über Geldabwertungen, ed. and tr. Wolfram Burckhardt (Berlin: Kadmos, 1999). For further reading, see Hendrik Mäkeler, 'Nicolaus Oresme und Gabriel Biel. Zur Geldtheorie im späten Mittelalter', Scripta Mercaturae, 37 (2003), 56-94.

40 'Moneta pura thesaurus est. qui enim id genus nummos aureos \& argentos possidet, scit quid habeat: \& quod habeat ubique tantum valet.' Georgius Agricola, 'De precio metallorum et monetis libri III', in idem, $D e$ mensuris $\mathcal{E}$ ponderibus Romanorum atque Graecorum lib. V (Basel, Froben: 1550), 253-340, here 271.
} 
instabilities and uncertainties of the monetary system are articulated as well, as the Wild Man also stands for the unknown and the unexplored.

Just as at this discursive level, the coin's power was instrumentalized more explicitly within a concrete political debate. Heinrich used the Wild Man's unpredictable ferociousness to substantiate his claim on his authority in a harsh conflict with the city of Goslar, dating back to $1526 .{ }^{41}$ In this year the duke settled financial debts originating from the late thirteenth century, when his ancestors mortgaged mining and forestal areas to Goslar's town council. ${ }^{42}$ He reclaimed the rights over wood resources and the output of the silver mines for himself and deprived the citizens of the Imperial City of their traditional source of income. The Wild Man as a symbol for the forest and the mines reinforced Heinrich's claim in his case against the city. His conflict with Goslar heightened when the city was put to siege, which led to its capitulation in 1552. By placing the Wild Man on his coins the duke showed his uncorrupted, good side but at the same time communicated the threat of his anger.

\section{TAMING THE WILD MAN}

Julius of Braunschweig-Wolfenbüttel (1528-1589), who took over the duchy in 1568, chose for his first series of thaler coins the same Wild Man chosen by his father Heinrich, but instead of an ore specimen, the creature holds a candle in his hands (Fig. 2). ${ }^{43}$ This thalerwas minted between 1569 and 1589. Between 1586 and 1589 a further variant was issued with the Wild Man holding an oil lamp in his hand and additionally a skull, glasses, and an hourglass hanging from his arm (Fig. 3). These coins' connection to mining and to silver is only represented in their material quality as silver coins. The ore specimen has been removed from the Wild Man's hand in favour of vanitas symbols. Julius inscribed his preferred motto on the coin: Aliis inserviendo consumor [I will be consumed, by serving others]. Again, placed on a coin, this inscription characterizes the nature of the Wild Man and of the coin at one and the same time. Just as it became the creature's new duty to serve the territory by providing natural riches, it was money that serves while being consumed. The

\footnotetext{
${ }^{41}$ Frederick J. Stopp analysed the attribution of Wild Man to Heinrich the Younger in detail. One shortcoming of this very rich and compelling article is that the material and medial quality of money and the practice of minting is not acknowledged. Frederick J. Stopp, 'Henry the Younger of Brunswick-Wolfenbüttel. Wild Man and Werwolf in Religious Polemics 1538-1544', Journal of the Warburg and Courtauld Institutes, 33 (1970), 200-34.

${ }^{42}$ For further reading on the conflict between Heinrich and Goslar, see Christoph Bartels, 'Die Stadt Goslar und der Bergbau im Nordwestharz. Von den Anfängen bis zum Riechenberger Vertrag von 1552', in Karl Heinrich Kaufhold, Stadt und Bergbau (Cologne: Böhlau Verlag, 2004), 135-88; Ekkehard Henschke, 'Die Wolfenbütteler Herzöge und der Bergbau im Harz', Braunschweigisches Jahrbuch für Landesgeschichte, 88 (2007), 71-88; Ekkehard Westermann, 'Der Goslarer Bergbau vom 14. bis zum 16. Jahrhundert. Forschungsergebnisse - Einwände - Thesen', Jahrbuch für die Geschichte Mittel- und Ostdeutschlands, 20 (1971), 251-61.

${ }^{43}$ For Julius' economic thought see the seminal study of Hans-Joachim Kraschewski, Wirtschaftspolitik im deutschen Territorialstaat des 16. Jahrhunderts. Herzog Julius von Braunschweig-Wolfenbüttel (1528-1589), (Cologne: Böhlau, 1978).
} 

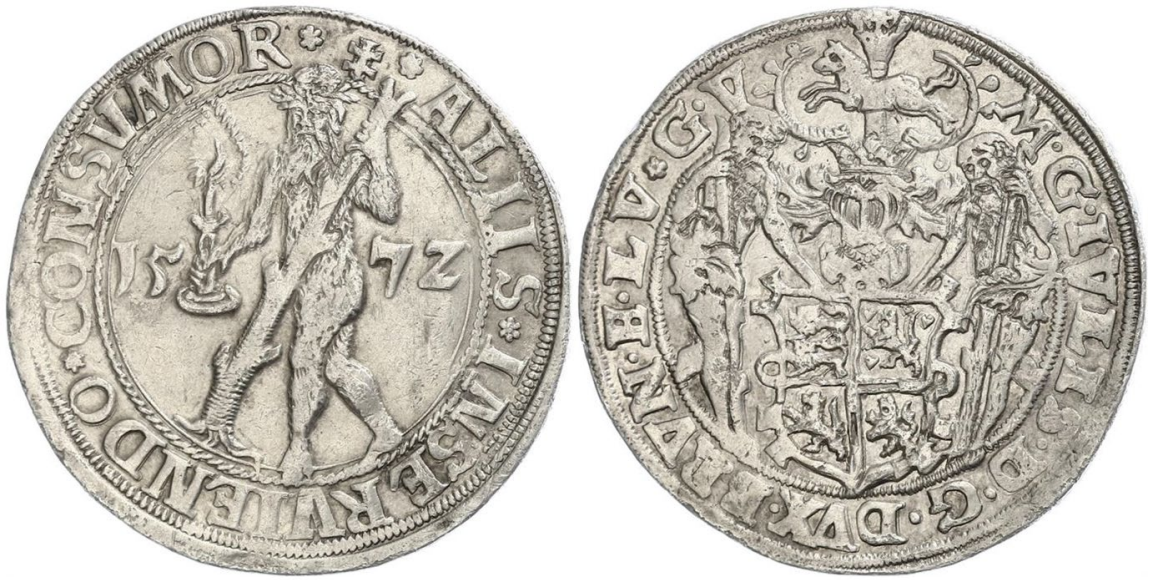

Fig. 2 Wilder Mann thaler with candle, Julius of Braunschweig-Lüneburg, minted in Goslar by Andreas Köhne, 1572, silver 28.95 g, $41 \mathrm{~mm}$. Niedersächsisches Münzkabinett der Deutschen Bank Hannover (@ Niedersächsisches Münzkabinett der Deutschen Bank Hannover)
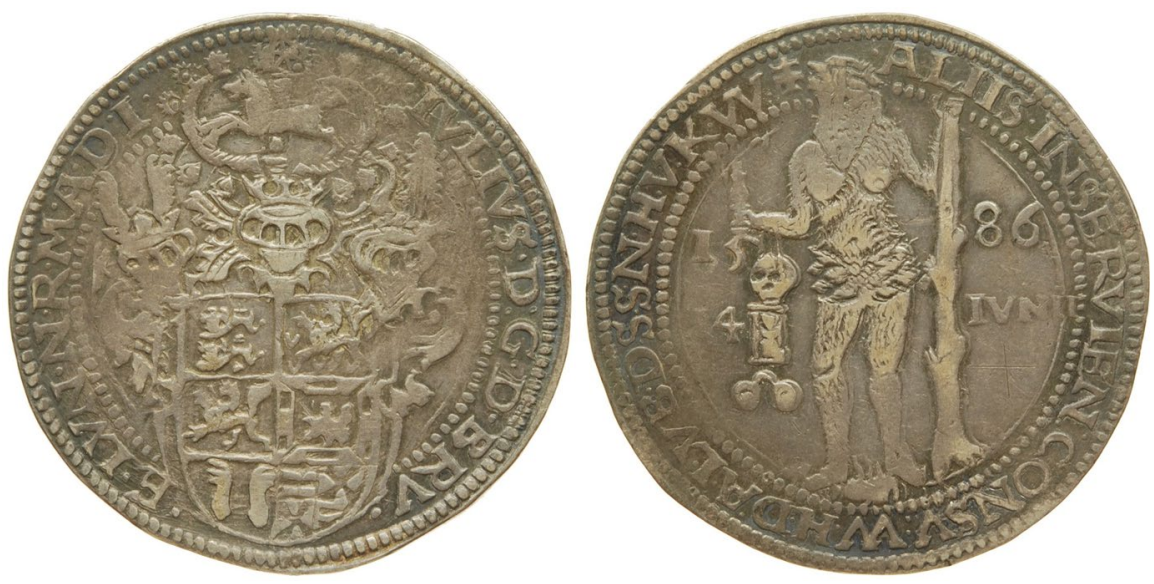

Fig. 3 Brillentaler, Julius of Braunschweig-Lüneburg, minted in Goslar by Andreas Köhne, 1586, silver 28.98 g, 42 mm. Münzkabinett, Staatliche Kunstsammlungen Dresden, Inv.-Nr. 2015/1068 (@ Münzkabinett, Staatliche Kunstsammlung Dresden)

emphasis, thus, moved from treasure, represented by the Wild Man holding an ore specimen, to consumption represented by the creature holding a burning candle. His new function as servant was further indicated by the depiction of the Wild Man as a light bearer, which turns him into an essential guide through the dark underground workings but marks him also as a link to the world outside above ground: the world of commerce and trade. 
The connection of the Wild Man with mining, commerce, and trade is made even clearer by a new type of coin, the Julius Löser, or just Löser, issued between 1574 and $1588 .{ }^{44}$ These coins were minted in different values (of 10, $9,5,4 \frac{1}{2}, 4,3,2^{1 / 2}$ thaler). Numismatic literature from the end of the seventeenth and the beginning of the eighteenth century discusses them widely. The eighteenth-century Philipp Julius Rehtmeyer (1678-1742), a priest and chronicler of Braunschweig, locates these Löser in the context of Julius' mercantilist economic thought: we read that every inhabitant of the duchy of Braunschweig-Wolfenbüttel had to buy them according to their provision and was obliged to store them. Once a year the possession of the coin had to be shown to the authorities. According to Rehtmeyer these coins were not minted as currency to be put into circulation as such, they rather had the specific function of saving or storing money. If the duke needed money, he could borrow these Löser, melt them down and produce currency. As soon as the shortage was resolved, new Löser were produced, which then were given back to the creditors. ${ }^{45}$

No historians nor numismatists have been able to verify Rehtmeyer's claims. ${ }^{46}$ However, a closer look at the monetary practices of the second half of the sixteenth century makes Rehtmeyer's interpretation seem problematic. The Julius-Löser seemed to be intended as currency. The golden Portugalöser or Portugaleser served as a model for Julius' Löser. ${ }^{47}$ The Portugalöser were minted in Hamburg after 1560, based on the model of the Português - a hefty gold coin worth ten Cruzados, minted since 1499 with gold from Africa. ${ }^{48}$ The Portugalöser were primarily intended as currency, particularly for the payment of larger sums such as those incurred in long-distance trade, and they were well known. In the seventeenth century they gradually lost their significance as currency and the term Löser came instead to describe medals and commemorative coins. $^{49}$

${ }^{44}$ Leschhorn, Braunschweigische Münzen und Medaillen, 135-9.

45 'Diese merckwürdige Münze in hat ein jeglicher Unterthan nach seinen Rang in grossern udn kleinern Werthe mit andern Gelde einlösen, stets behalten und verwahre, auch alle Jahr der Obrigkeit jedes Orts vorzeigen müssen: Die von geringen Vermögen haben solche Löser, welche zwey Thaler wert, die Wohlhabenden aber andere, welche drey, vier, fünf bis zehn Thlr. gegolten, eingelöst; und solcher gestalt hat man wissen können, wie viel Geld, welches ohne Zinsen Müßig gelegen, im ganzen Lande verhanden wäre, da denn im Nothfall der Landes-Herr solche Julius-Löser von den Unterthanen aus einem oder mehr Aemtern entlehnen, und andere gangbare Münze daraus schlagen können; wenn solches geschehen, und er sich damit fortgeholffen, hat er hernach die Löser wieder prägen, das davor versetzte einlösen, und denen Unterthanen wieder zustellen lassen.' Julius Philipp Rehtmeyer, Braunschweig-Lüneburgische Chronica, Vol. ii (Braunschweig: Arnold Jacob Keiteln, 1722), 1012.

${ }^{46}$ Leschhorn, Braunschweigische Münzen und Medaillen, 136; Kraschewski, Wirtschaftspolitik, 113-19.

${ }^{47}$ Ernst Henri Balan, 'Portugalöser-Juliuslöser. Über den Ursprung und die Bedeutung des ersten Mehrfachtalers Braunschweig-Lüneburgs auf breitem Schrötling', in 'Belehrungen und Unterhaltungen im Fache der Münzkunde [...]'. Die Numismatische Gesellschaft zu Berlin gegründet am 22. Dezember 1843. Festschrift zum 150-jährigen Bestehen (Berlin, 1993), 117-27;

${ }^{48}$ Friedrich von Schrötter, Wörterbuch der Münzkunde, (Berlin: De Gruyter, 1970), 298.

49 Max von Bahrfeldt, 'Über die älteren Hamburger Portugalöser', in Zeitschrift des Vereins für Hamburgische Geschichte, 19 (1917), 1-37. 
Julius' effort in mining and commerce makes this interpretation seem to be rather plausible. Just as his father Heinrich the Younger had done, Julius regarded silver, copper, and lead mining as a major source of income for his state and even expanded his activities in this sector. The income from the mines and metalworks accounted for $39.6 \%$ of all revenue at the Wolfenbütteler chamber between 1579 and $1580 .{ }^{50}$ Julius not only possessed the highest number of mining shares, he also invested in mining technology, processing manufactures and the expansion of the waterway transport network for the transportation of raw materials and the output from his mines. ${ }^{51}$ The processing and manufacturing sites of Braunschweig and Lüneburg produced a huge variety of mining products, the so called Bergwaren (mainly lead, brass, iron, alabaster, and vitriol). ${ }^{52}$ The latter were advertised splashily throughout the country and in major trading cities like Antwerp and Amsterdam. ${ }^{53}$ In the years between 1572 and 1586, the duke sent a few dozen letters to the councils of the Hanseatic Cities and to several Central and Eastern European courts, praising the wealth of his country and listing his Bergwaren. ${ }^{54}$ Accordingly, we have to contextualize these Löser coins within Julius' broader plans to transform his duchy into a leading centre of industry and trade.

As curious as the Löser's purpose is its design (Fig. 4). The obverse shows Julius' portrait in full armour holding a battle-axe with his right hand and in his left a sword. Four circles surround his portrait. The inner circle depicts the seven known planets visualized anthropomorphically, the outer circle shows the twelve zodiac symbols, followed by two inscribed circles: 'By Grace of God Duke Julius of Braunschweig and Lüneburg, God's provision must be given/ O Lord do not protect more than my body, soul, and honour'. ${ }^{55}$ The reverse depicts the ducal coat of arms accompanied by two Wild Men, both holding a halberd, with the creature on the right additionally holding a candle, the figure on the left an imperial orb. Again, four circles surround the coat of arms, the inner circles show the seven planets and the twelve zodiac signs, the outer

\footnotetext{
${ }^{50}$ Bartels, Vom frühneuzeitlichen Montangewerbe zur Bergbauindustrie, 47.

${ }^{51}$ In the year 1588/89 Julius possessed the highest number of shares (i.e. 128) in four different pits. Additionally, he possessed 855 Kuxen from 44 pits. For more quantitative material see Henschke, Landesherrschaft und Bergbauwirtschaft, 304.

${ }^{52}$ In 1582 Julius calculated the value of his mining products, the Bergwaren, which were located in his storehouses in Wolfenbüttel as 700,000 Reichsthaler worth. But this incredible material wealth was not meant to be stored as mere treasure, but to be sold. Henschke, Landesherrschaft und Bergbauwirtschaft, 320 .

${ }^{53}$ Carl W. Sack, 'Herzog Julius von Braunschweig Lüneburg als Fabrikant von Bergwerks-Erzeugnissen des Harzes sowie als Kaufmann. 1568ff', Zeitschrift des Harzvereins für Geschichte und Altertumskunde, 3 (1870), 305-27.

${ }^{54}$ Aleksandra Lipińska, 'Alabasterdiplomatie. Material als Medium herrschaftlicher Repräsentation und als Vernetzungsinstrument in Mittel- und Osteuropa des 16. Jahrhunderts', in Magdalena Bushart, Henrike Haug, and Aleksandra Lipińska (eds.), Gemeine Artefakte. Zur gemeinschaftsbildenden Funktion von Kunstwerken in den vormodernen Kulturräumen Ostmitteleuropas, kunsttexte.de [online], 2014, https://edoc.hu-berlin.de/bitstream/ handle/18452/8208/lipinska.pdf (accessed May 2018).

${ }^{55}$ VON G[ottes] G[naden] IVLIVS HERTZ Z BRVNSWIG V LVNEBVRG GOTTES VERSEHEN MUS GESCHEHEN/ O HER BEHVT MIR NICHT MER DAN SEEL LEIB VNDT EHR.
} 
circles an inscription: 'New coin, minted in Heinrichstadt according to the Imperial currency ordinance [nach des Reichs Schrot und Korn] with name Julius of Brunsvick's Löser of 10 thaler's value. ${ }^{, 56}$ The inscription nach des Reichs Schrot und Korn gives assurance of the Löser's stability and reliability. Two Wild Men, the strong and reliable servants of Braunschweig-Wolfenbüttel, protected this above ground silver deposit. The depiction of zodiac signs and the personification of the planets was a completely new design, not previously in evidence. ${ }^{57}$ The planets especially relate to the alchemical view of the generation of minerals (or metallogenesis). As Warren Dym and John Norris have recently discussed, medieval and early modern natural philosophers, mining practitioners and metal workers adopted an organic conception of ores, according to which veins grew organically by means of astral influences, underwent a natural life cycle of generation and decay, and even regenerated years after depletion. ${ }^{58}$

In the later sixteenth century, alchemical ideas were adopted in mining through the publication of the works of Paracelsus. ${ }^{59}$ Duke Julius must have been well aware of this knowledge, since for him, alchemy had an important entrepreneurial and economic value. The secrets of nature and of art had long promised to be economically as well as politically useful. By hiring skilled assayers and alchemists, he tried to increase the productivity of the mines and the fertility of his lands. ${ }^{60}$ The zodiac signs and planets on Julius' Löser kept the metal alive and in a sense fertile. These coins symbolized a repository of wealth

\footnotetext{
${ }^{56}$ NEWE MVNTZ GEPREGE ZV HEINRICHSTADT NACH DES REICHS SCHROT VND KORN GENAND / BRNSWIGS IVLIVS LOSER AM WERT X TALER.

${ }^{57}$ The ordering of the planets and zodiac signs still puzzles scholars today. Interestingly, in the first Löser issue the zodiac signs are depicted in anticlockwise order, beginning with Libra. From about 1578 on this changed into a clockwise order, beginning with Taurus. The order of the planets also changed from 1574 to 1578, but a deeper sense behind this order could not be detected yet. 1574: Sol, Luna, Mars, Mercury, Saturn, Venus, Jupiter and 1578: Saturn, Jupiter, Mars, Sol, Venus, Mercury, Luna.

58 This natural philosophy was a mixture of classical and Arabic theory, much indebted to Albertus Magnus's De mineralibus (first printed in 1476), which had introduced Arabic alchemy to Christian scholars. See for a recent publications John Norris, 'Early Theories of Aqueous Mineral Genesis in the Sixteenth Century', Ambix 54 (2007), 69-86; Alexander Warren Dym, 'Alchemy and Mining: Metallogenesis and Prospecting in Early Modern Mining Books', Ambix 55 (2008), 232-54.

${ }^{59}$ In one of the earliest mining books, Eyn wohlgeordnet und nützlich büchlein, wie man bergzerk suchen und finden soll [A well-ordered and useful little book about how to seek and find mines] or Bergbüchlein written by Ulrich Rülein von Calw around 1500, Daniel, the protagonist and a learned miner, explains to his pupil the interconnection between heaven and Earth and how celestial bodies influence and shape earthly substances. Rülein von Calw, Eyn wohlgeordnet und nützlich büchlein, wie man bergwerk suchen und finden soll, (Worms: Peter Schöfer, 1518), n.p., Wilhelm Pieper, Ulrich Rülein von Calw und sein Bergbüchlein (Berlin: Akademie Verlag, 1955); David E. Conolly, 'Ulrich Rülein von Kalbe's 'Bergbüchlein' in the Context of Sixteenth-Century German Mining/Metallurgical Literature', in Robert Bork (ed.), De Re Metallica. The Uses of Metal in the Middle Ages (Aldershot: Ashgate 2005) 347-66.

${ }^{60}$ For further literature on Julius' interest in alchemy, his collections of alchemical literature, and alchemical practices at his court, see: Tara Nummedal, Alchemy and Authority in Holy Roman Empire (Chicago: Chicago University Press, 2007); Petra Feuerstein-Herz and Stefan Laube (eds.), Goldenes Wissen: die Alchemie - Substanzen, Synthesen, Symbolik. Ausstellung der Herzog August Bibliothek Wolfenbüttel, vom 31. August 2014 bis zum 22. Februar 2015 (Wiesbaden: Harrassowitz, 2014); Albert Rhamm, Die betrüglichen Goldmacher am Hofe des Herzogs Julius von Braunschweig. Nach den Proceßakten (Wolfenbüttel: Julius Zwißler, 1883). For further literature on entrepreneurial alchemy, see especially Pamela H. Smith's classic study, Pamela H. Smith, The Business of Alchemy: Science and Culture in the Holy Roman Empire (Princeton: Princeton University Press, 1994).
} 
above ground, which is not simply stored in an inert and passive way, but is rather active and reproductive, in the way it is used in commerce and trade. This idea relates to broader political literature of the late sixteenth and seventeenth centuries. Vera Keller has compellingly analysed how political writers such as Botero, Bacon, Bornitz, and Bernegger used the metaphor of the mine above ground. The above ground mines "were the mines of industry and commerce from which, via the complicated interactions of global supplies and demands, more silver could be extracted than from the direct mining of nature'. ${ }^{6}$
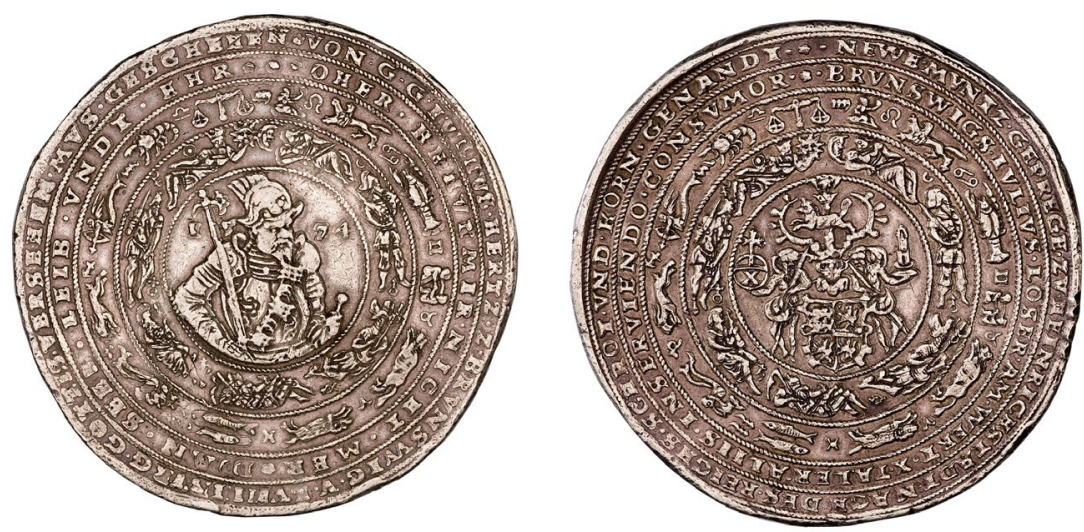

Fig. 4 Julius Löser, value of 10 Reichstaler in Heinrichstadt, 1574; silver $261.68 \mathrm{~g}, 74 \mathrm{~mm}$ Braunschweig Münzforschungssammlung der NORD/LB, Inv.-Nr. 205 () Braunschweig Münzforschungssammlung der NORD/LB)

Even though he was transferred from the aforementioned unruly mining landscapes to the world of commerce, the Wild Man's ambivalent, violent, and unpredictable nature did not disappear entirely. In fact, his sphere of action even grew wider: of significant economic importance here were the iron mines and the manufacturing industries. ${ }^{62}$ Iron was a material that became prominently associated with the Wild Man during Julius' reign as well. Some of the most popular items of trade were cannonballs made of iron slag and iron artillery. ${ }^{63}$ A huge gun barrel made of iron which bore the name Wilder Mann was stored in the arsenal of Wolfenbüttel and is now located in the Deutsches Historisches Museum in Berlin. Almost six metres in length, it is one of the longest sixteenth-century Hinterlader [breech-loader] so far discovered

\footnotetext{
${ }^{61}$ Vera Keller, 'Mining Tacitus: Secrets of Empire, Nature and Art in the Reason of State', BJHS, 45 (2012), 189-212.

${ }^{62}$ Kraschewski, Wirtschaftspolitik, 144-7.

${ }^{63}$ It was claimed that the duke invented these Schlackenkugeln in 1569 with waste material from his mines. Arne Homann, 'Artilleriegeschosse aus Schlacke - Eine welfische Erfindung des 16. Jahrhunderts', Braunschweigisches Jahrbuch für Landesgeschichte 96 (2015), 11-26.
} 
(Fig. 5) ${ }^{64}$ The mouth of the canon barrel bears the face of a beast and on the long side, or Kanonenrohr, we can see a representation of a Wild Man holding a trunk in his left hand and a banner in his right. It states: Ich heis der eisen wilde man und breche was nicht biegen kann [I'm named the Wild Iron Man/ I break more than bending can].

While Duke Heinrich's Wild Man thalerwas both a symbol of ducal power and a manifestation of broader discourses about the relationship between natural wealth or natural riches and the production of value by 'artificial' means (with all this implies), Julius' Wild Man thaler relates to a process of domestication, wherein the Wild Man was fashioned as a servant, who exclusively carried out the wishes of the duke. The power of the Wild Man would crush all opposition. His incredible strength and his arcane knowledge were no longer represented as uncontrollable forces. Apart from the sovereign ruler's authoritarian claims and the way his power was represented, the world of commerce and trade, with which the Wild Man had also become associated, demonstrated a far more complex sphere. Trade was as tricky to control with iron and artillery just as much as with sophisticated Löser coins. The archival records reveal that Heinrich the Younger as well as Julius were constantly looking for foreign merchants and mining entrepreneurs with whom to cooperate, and continued to seek out wealthy investors. ${ }^{65}$ The merchant Veit Wittich and his fellow investors from Augsburg for instance were the major shareholders of two pits, St Jakob and the Sachsen-Zeche, until 1581. ${ }^{66}$ Therefore, even if the taming of the Wild Man is a claim made by the authorities, as they extended the state's administrative reach, we should be careful not to overestimate the sovereign's role here as a political one man show. ${ }^{67}$ The above ground mines of commerce were thus much harder

\footnotetext{
${ }^{64}$ Heinrich Müller, Das Berliner Zeughaus. Vom Arsenal zum Museum (Berlin: Berlin Brandenburgesches Verl. Haus, 1994), 125; Wanecke, Carl Otto, 'Feldschlange und Wilder Mann', Allgemeiner Harz-Berg-Kalender, (1976), 99.

${ }^{65}$ Friedrich Günther, 'Ein Versuch des Herzog Julius zur Belebung des Bergbaus', Zeitschrift des Harz-Vereins für Geschichte und Altertumskunde, 43 (1910), 107-17.

${ }^{66}$ Henschke, Landesherrschaft und Bergbauwirtschaft, 215.

${ }^{67}$ An important particularity that characterized the mining industry of Heinrich the Younger and his son Julius was the dominant position of the sovereign. Especially the latter expanded the mining administration and took the organizational, financial, and technical decision-making process into his own hands. In the seventeenth century, however, the sovereign's shrinking influence becomes evident, when local mining officials began to assume his function, both in management and investment. In a recent review Franziska Neumann warns against projecting the ideal of an absolutist directorial system (Direktionsprinzip) onto the emerging mining industry. Contrary to what the normative sources of the early modern mining regions might suggest, the power structures and the opportunities of influence within the mining practices were far more nuanced and convoluted. Franziska Neumann, 'Review of Klaus Tenfelde / Stefan Berger / Hans-Christoph Seidel (eds.), Geschichte des deutschen Bergbaus. 1: Der alteuropäische Bergbau. Von den Anfängen bis zur Mitte des 18. Jahrhunderts, Münster: Aschendorff, 2012' in Zeitschrift für Historische Forschung (ZHF), 42 (2015), 1, 75-7. Christoph Bartels already mentions the underestimation of the shareholders (Gewerken) within the narrative of a (proto-)absolutist mining industry, see: Bartels, Vom frühneuzeitlichen Montangewerbe zur Bergbauindustrie, 53. For broader information on Julius' economic policy and thought, see Kraschewski, Wirtschaftspolitik; idem, 'Organisationsstrukturen der Bergbauverwaltung'; idem, 'Wirtschaftspolitische Grundsätze des Herzog Julius von Braunschweig Wolfenbüttel und seiner leitenden Montan- und Finanzbeamten', in Angelika Westermann (ed.), Wirtschaftslenkende Montanverwaltung, fürstlicher Unternehmer, Merkantilismus (Husum: Matthiesen Verlag, 2009), 195-227.
} 


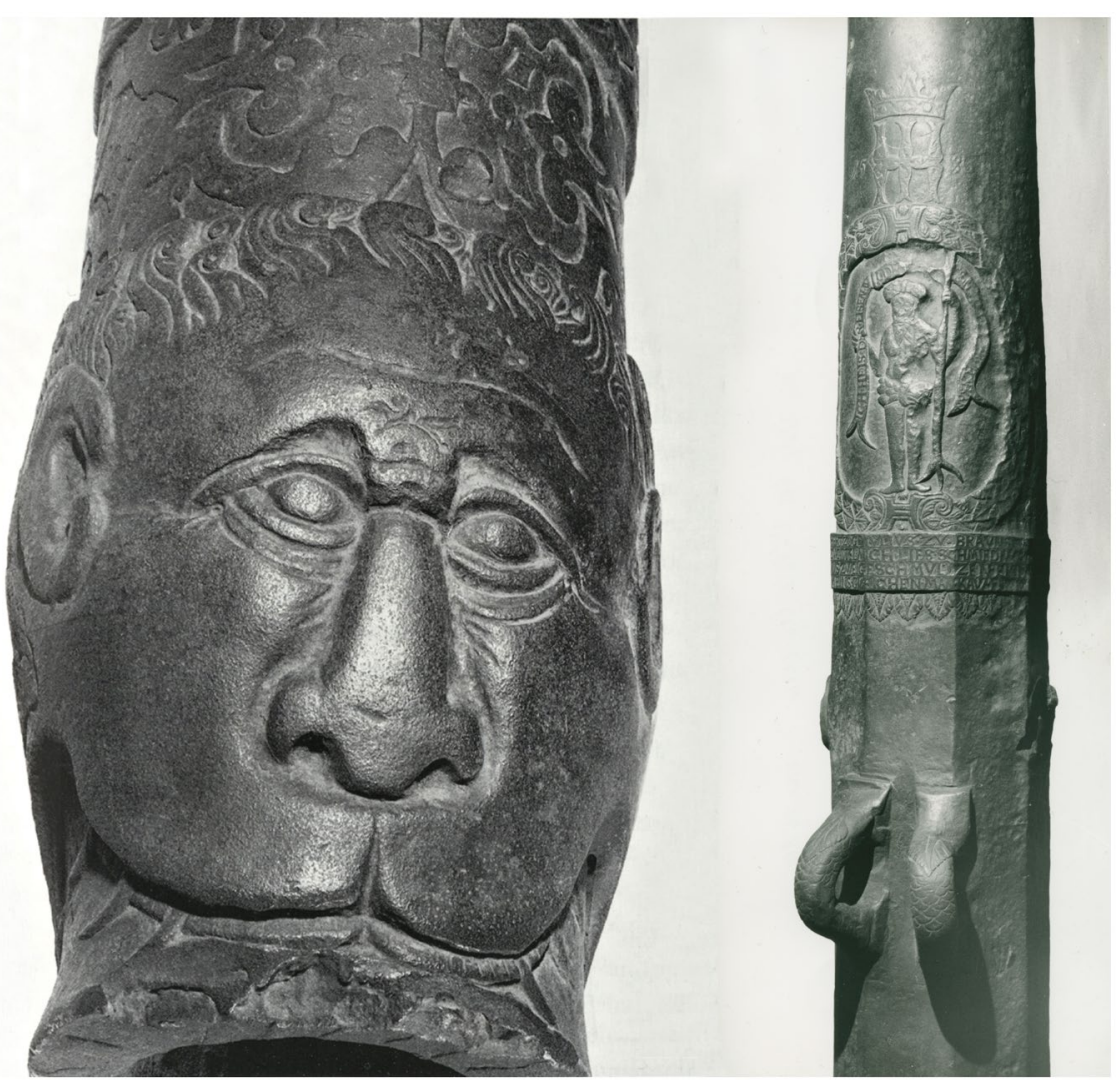

Fig. 5 Cannon [Feldschlange] entitled 'der Wilde Mann' of Herzog Julius von BraunschweigLüneburg, probably made by Christian Hausen from Gittelde (Harz), 1586. 580 cm, 3,700 kg. Deutsches Historisches Museum Berlin (CDeutsches Historisches Museum Berlin)

to predict, control, and to 'tame' than the Löser's iconography of economic fertility and material reproduction suggested. Compared to the expenditure incurred by advertisement, the sale of the Bergwaren was not at all as profitable as expected. In 1587 Julius even discussed lowering the production rates with his chief mining official Christoph Sander, because the store houses at Wolfenbüttel were full and no buyers seemed to be in sight. ${ }^{68}$

After Julius' death in 1589 the Wild Man thaler continued to appear, and in 1600 it became a specific symbol of the newly founded mint in Zellerfeld. The Wild Man thus moved back from the ducal residence at Heinrichstadt to the mining region in the Upperharz, the place from where he originally came. In this new location, the Wild Man continued to become ever more

\footnotetext{
${ }^{68}$ Henschke, Landesherrschaft und Bergbauwirtschaft, $320 \mathrm{f}$.
} 
domesticated. The taming of the Wild Man had important consequences for the way local natural riches were perceived. He no longer symbolized the essential precariousness of prospecting for silver, but rather became increasingly fashioned as a warrantor for mineral wealth as well as a symbol for the constancy and stability of the mining business as it continued in the Harz region, and for the stability of the currency as well. On coins minted under the rule of Duke Friedrich Ulrich of Braunschweig-Wolfenbüttel (1591-1634) after 1613 in Zellerfeld, the Wild Man underwent a fashionable brush up and came to resemble a figure more akin to Hercules (Fig. 6). The thick coat he had formerly worn almost fully disappeared, a loincloth made of foliage modestly covered his genitals, his beard was well brushed and styled in a trendy shape, and his head was covered with a hood made of twigs. With his altogether honest visual appearance, the succeeding dukes promoted ideas of stability and reliability.

One example in particular represents a Wild Man Ausbeutetaler issued under Christian Ludwig of Braunschweig-Lüneburg-Celle (1622-1665) in 1663 and 1665 (Fig. 7). It shows a giant, muscular Wild Man standing over a busy mining scene. He is depicted holding a tree trunk, which resembles Hercules' club, in his right hand. The inscription represents Christian Ludwig's motto sincere et constanter [honest and constant]. These multiple thaler coins were intended as payment for the investors of the Harz mines. The major part of these shares from the Upper Harz mines were owned by the mining officials, who took management and ownership into their own hands just as the Dukes had done before them. Evidently, the officials were anything but neutral
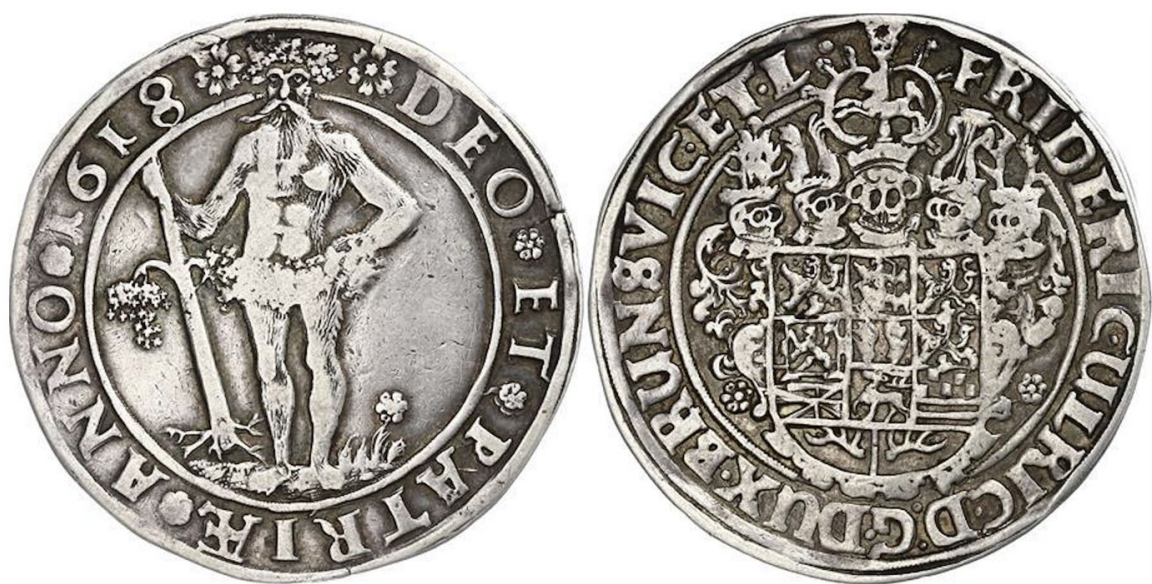

Fig. 6 Wilder Mann thaler, Friedrich Ulrich of Braunschweig-Lüneburg, minted in Zellerfeld by Heinrich Oeckeler, 1618; silver 28.71 g, 34 mm (@ Fritz Rudolf Künker GmbH \& Co. KG, Osnabrück und Lübke \& Wiedemann, Stuttgart) 

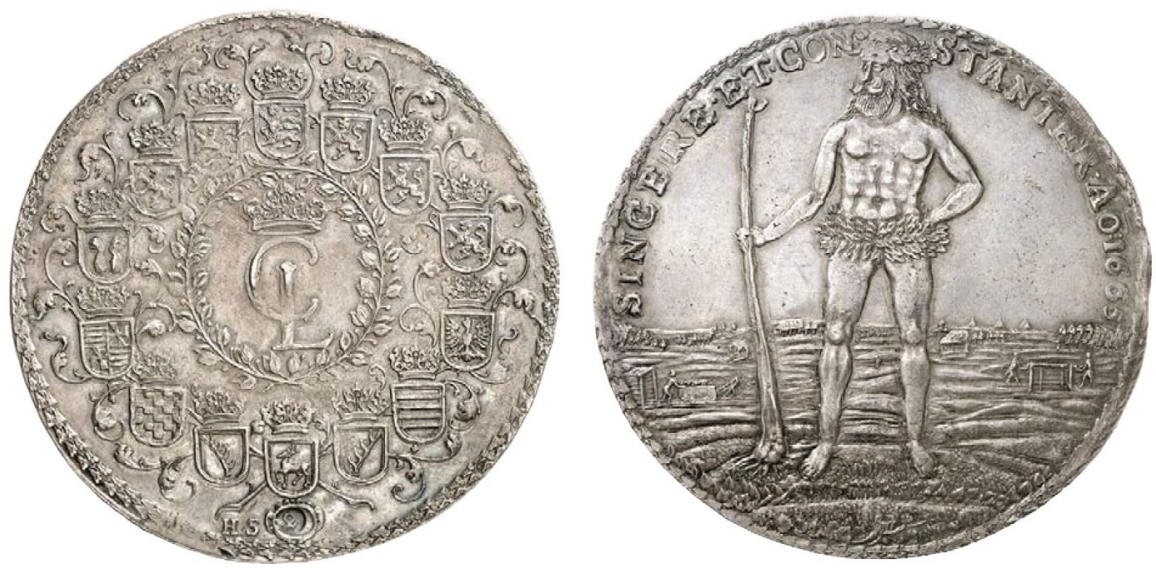

Fig. 7 Ausbeutetaler, Christian Ulrich of Braunschweig-Lüneburg-Celle, value of 3 Reichstaler, minted in Zellerfeld by Henning Schlüter, 1665, $86.31 \mathrm{~g}$ (@ Fritz Rudolf Künker GmbH \& Co. KG, Osnabrück und Lübke \& Wiedemann, Stuttgart)

trustees. ${ }^{69}$ The presence of the Hercules-like Wild Man on an Ausbeutetaler shows how the officials appropriated the visual rhetoric of the sovereign and adapted the Wild Man as a signifier of stability and constancy into an emblem for their mining business.

\section{CONCLUSION}

Far from being a purely negative force that had to be defeated, the Wild Man of the Harz Mountains was a useful resource, not only on the level of the state's (o)economy but also for the individuals who risked their lives in the mines and for those who dared to invest in their operation. In their daily actions and experiences, the government, as well as individuals such as sovereigns, mining officials, mint masters, investors, hewers, physicians, and others involved in the mining industry were confronted with the uncertain, dangerous, and risky nature of mining. They nevertheless challenged nature in multiple ways, such as finding technical solutions to solve problems of invading ground water, an insufficient air supply, or invented new assaying methods for processing poor ores. But they also challenged themselves, pushed against their own bodies and beliefs, by withstanding hard physical labour or accepting the lure of material desires or the greedy search for natural riches. These early modern actors, thus, tried to stabilize the ferocious,

\footnotetext{
${ }^{69}$ Bartels, Vom frühneuzeitlichen Montangewerbe zur Bergbauindustrie, esp. 52-54.
} 
uninhibited, and untamed nature of the Wild Man by establishing a kind of resolve that can be traced through the development of administrative and financial structures, to the construction of shafts, the deployment of innovative technologies and on into the miner's body itself, with its values, emotions, and beliefs. But this robustness nevertheless relied upon a fragile stability, a stability that the Wild Man's ferocious, wild, and unchristian nature always threatened to tear down.

This article has analysed practices and modes of resistance concerning the Wild Man's taming and his appropriation into the world of commerce and trade. This analytical perspective examined consolidation processes regarding financial mechanisms and administrative structures, by acknowledging the discursive powers that are inherent in symbolic forms and their affective operation and that are too often dismissed as thin or superficial ephemera within the greater debate.

ETH Zürich 